\title{
SWOT Analysis for the Promotion of Energy Efficiency in Rural Buildings: A Case Study of China
}

\author{
Lin Zhang ${ }^{1}$, Shan Guo ${ }^{2,3, *}$, Zezhou $\mathrm{Wu}^{4}{ }^{4}$, Ahmed Alsaedi ${ }^{3}$ and Tasawar Hayat ${ }^{3,5}$ \\ 1 School of Management Engineering, Shandong Jianzhu University, 1000 Fengming Road, Licheng District, \\ Jinan 250101, China; zhanglin2007@sdjzu.edu.cn \\ 2 Department of Land Management, School of Public Administration and Policy, Renmin University of China, \\ Beijing 100872, China \\ 3 NAAM Group, Faculty of Science, King Abdulaziz University, 21589 Jeddah, Saudi Arabia; \\ aalsaedi@kau.edu.sa (A.A.); tahaksag@yahoo.com (T.H.) \\ 4 Department of Construction Management and Real Estate, Shenzhen University, Shenzhen 518060, China; \\ wuzezhou@szu.edu.cn \\ 5 Department of Mathematics, Quaid-i-Azam University, 45320 Islamabad, Pakistan \\ * Correspondence: shan.guo@ruc.edu.cn; Tel.: +86-188-1176-3368
}

Received: 14 March 2018; Accepted: 3 April 2018; Published: 5 April 2018

check for updates

\begin{abstract}
Over half of China's total energy consumption is attributed to rural buildings. However, unlike the research into urban areas, few studies have explored the problems of building energy efficiency (BEE) in rural China. This study aims to establish an appropriate strategic plan for promoting rural BEE (RBEE) in China by conducting a strength-weakness-opportunity-threat (SWOT) analysis. Analysis data are obtained from multiple sources, including a comprehensive literature review, governmental reports, related regulations, and semi-structured interviews with a number of critical stakeholders. A matrix of the SWOT analysis is derived to reveal the drivers and barriers in the course of implementing RBEE. Five critical strategies are proposed. We also attempt to explore the internal and external conditions of RBEE in China, which can contribute to the customization and prioritization of policy recommendations for the Chinese government.
\end{abstract}

Keywords: SWOT analysis; building energy efficiency; rural area; strategic planning

\section{Introduction}

The improvements in rural residents' earnings and living conditions have remarkably increased the building energy consumption in rural China, which accounts for approximately $40 \%$ of the total energy consumption of the country [1]. Most rural buildings are characterized by poor thermal insulation performance, which can barely meet the basic living standards of rural residents. Since the Chinese government launched the so-called "New Countryside Initiative" in 2005, local governments have been focusing on the construction of rural infrastructure and new housing types to realize the targets of economic prosperity and built environment improvement. In this context, improving rural building energy efficiency (RBEE) has emerged as a crucial issue. The Chinese government has gradually recognized the importance of RBEE, which is considered a major opportunity for improving national building energy efficiency (BEE) [2]. In March 2017, the Ministry of Housing and Urban-Rural Development (MOHURD) launched the "13th Five-Year Plan for Building Energy Saving and Green Building Development". The objective is for the energy consumption of rural buildings to make a breakthrough in economically developed areas and for key development areas to adopt over $10 \%$ energy-saving measures [3].

Unlike urban BEE, RBEE is still in the initial stage of development. Furthermore, urban BEE has witnessed significant progress in the last two decades. The practices related to BEE are mostly 
concentrated on the large-scale public, commercial, and urban residential buildings, with rural buildings receiving relatively little attention [4]. Moreover, rural buildings have not been included in the scope of mandatory criteria for BEE. Consequently, a significant gap in BEE exists between urban and rural regions.

Accelerating the promotion of RBEE has a potential strategic impact on reducing energy consumption and improving the living conditions of rural residents in the long run. The government plays an important role in implementing RBEE in the initial stage due to the externality and asymmetric information in the BEE market [5]. Therefore, strategic planning and the implementation of actions are urgently needed. Although the government has introduced ambitious energy efficiency targets in rural regions, the formulation of an applicable strategic plan remains unclear. The present study can contribute to the government's further understanding of the current situation and help in identifying the main problems and implementing effective measures [6]. Earlier studies have been conducted on RBEE, with the focus being the overview of the developments in RBEE [2,7], the assessment of RBEE [8], the critical factors to improve RBEE [9], and energy-saving optimization for the performance parameters of rural building shapes [4]. Research on the overview of the strengths, weaknesses, opportunities, and threats in RBEE is lacking. Thus, we aim to systematically express the status quo of RBEE and conduct a strength-weakness-opportunity-threat (SWOT) analysis of RBEE on the basis of a literature review, governmental reports, and semi-structured interviews. The established SWOT analysis strategic matrix on RBEE will enable the formulation of a strategic plan for government authorities.

\section{RBEE in China}

\subsection{Characteristics of Rural Residential Buildings}

Rural buildings are dramatically different from urban ones. Most rural buildings are traditional one-story or two-story stand-alone buildings with courtyards built on collective land for farmers [10], whereas urban buildings are commonly high-rise apartments [2]. For the longest time, farmers have constructed rural buildings by relying on their experiences, not on building construction codes. Therefore, the quality of the design and construction of rural buildings is lower than that of their urban counterparts. Research on building energy-saving technologies is mostly conducted for urban buildings. Energy conservation goals and mandatory standards also mainly target urban buildings.

Unlike urban housing, which has undergone rapid privatization, rural housing in China exhibits unique characteristics [11]. For example, in land ownership, rural residential lands are owned by village collectives, and an individual rural household can freely apply for one piece of residential land [10]. Therefore, current policies further entitle rural households with decision-making power in housing construction. Rural residents are wholly responsible for financing, constructing, managing, and maintaining their homes. Nevertheless, these houses cannot be traded in the market, and transfer is legally limited within villagers in the same household registration. All these characteristics imply that strategic planning for urban BEE cannot be replicated for RBEE.

Field investigation of real cases was conducted to clearly indicate the huge difference between urban and rural buildings. Two typical buildings in urban and rural Shandong, an eastern province of China, are illustrated in Figure 1. This traditional rural building was built in the countryside of Qufu, known as the hometown of Confucius, while high-rise housing was constructed in Jinan, the capital city of Shandong province. There are significant differences in terms of layout, building design style, cost, construction process, and, ultimately, levels of comfort and building energy efficiency. 


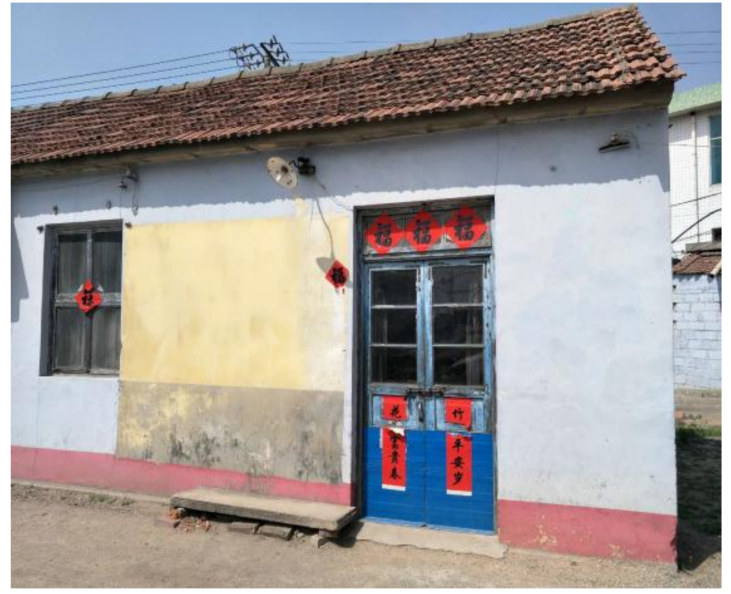

(a)

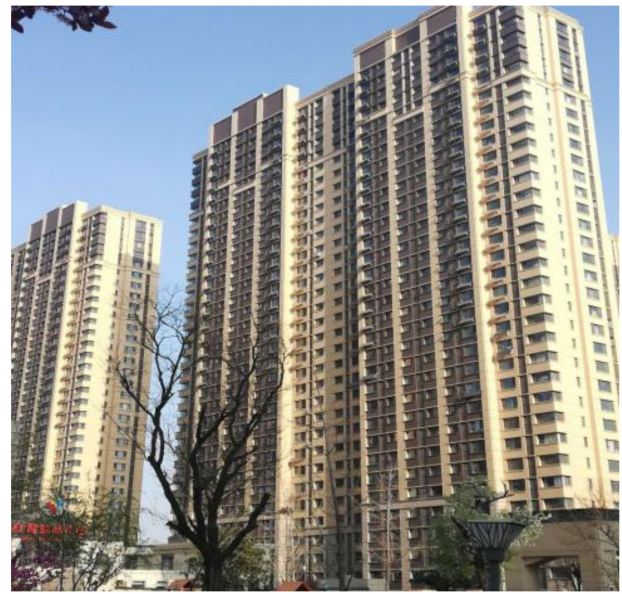

(b)

Figure 1. Different types of dwelling in the countryside and city. (a) a traditional village in Qufu, the hometown of Confucius in Shandong province; (b) the high-rise housing in Jinan, the capital of Shandong province, which was completed in 2015.

\subsection{Current Situation of RBEE}

With the development of rural regions in China, the energy consumption of rural buildings has gradually increased and accounted for a large proportion of the total. RBEE is not only a crucial issue of the New Socialist Countryside (NSC) and New Urbanization Initiative (NUI), but also an important field in energy efficiency and greenhouse gases that must not be overlooked. For instance, Wang, et al. [12] expressed that improving the living environment is an important indicator of the NSC. In March 2014, the "National New-Type Urbanization Plan (2014-2020)" was jointly launched by the Central Committee of the Communist Party of China and the State Council [13] to realize the sustainable development of rural energy. A series of studies have been conducted on energy consumption and greenhouse gas emissions at the global scale $[14,15]$, which can significantly influence the development of the world economy; at the national scale [16], including China; at the urban scale [17-19], including Beijing and Macao; and at the building scale $[20,21]$ with embodied energy consumption involved. However, rural regions have largely been neglected.

The data on energy consumption in rural buildings have been steadily expanding in recent years, as can be seen in a report on the development of Chinese building energy conservation in 2016 issued by the Science and Technology Development Promotion Center of the MOHURD. This report indicated that building energy consumption had increased from approximately 127 trillion ton coal equivalent to 161 trillion ton coal equivalent in the period of 2009-2013 [22] (Figure 2). The average annual growth reached $5.47 \%$. In 2013, the energy consumption of rural buildings in China increased to approximately $20.3 \%$ of the total. An increase in residents' income can be expected to boost the amount of energy consumption.

Problems have also gradually emerged in rural buildings. Most rural buildings in China lack energy-saving measures due to the limited knowledge about energy-saving technologies and experiences. For example, in northern China, a majority of rural buildings feature few insulation measures, poor air tightness for the doors and windows, and inefficient heating devices. The rate of energy utilization in rural buildings is only approximately one-third of that in urban buildings because of the poor thermal performance of the rural building envelope. A significant amount of heat is lost, and thermal comfort is inferior. Villages have no unified planning. Buildings also lack reasonable orientation. For instance, the adverse east-west orientation of buildings is undesirable for acquiring substantial amounts of sunlight and ventilation, thermal insulation in winter, and ventilation in summer, and it leads to considerable energy loss. The Statistics of Survey from the Tsinghua 
University and MOHURD in 2011 stated that the problems in RBEE include the absence of specialized planning, design, and construction, as well as necessary inspections and supervision of materials and the construction process, all of which lead to severe waste in land, materials, funds, and energy. Therefore, BEE should be promoted urgently in rural regions.

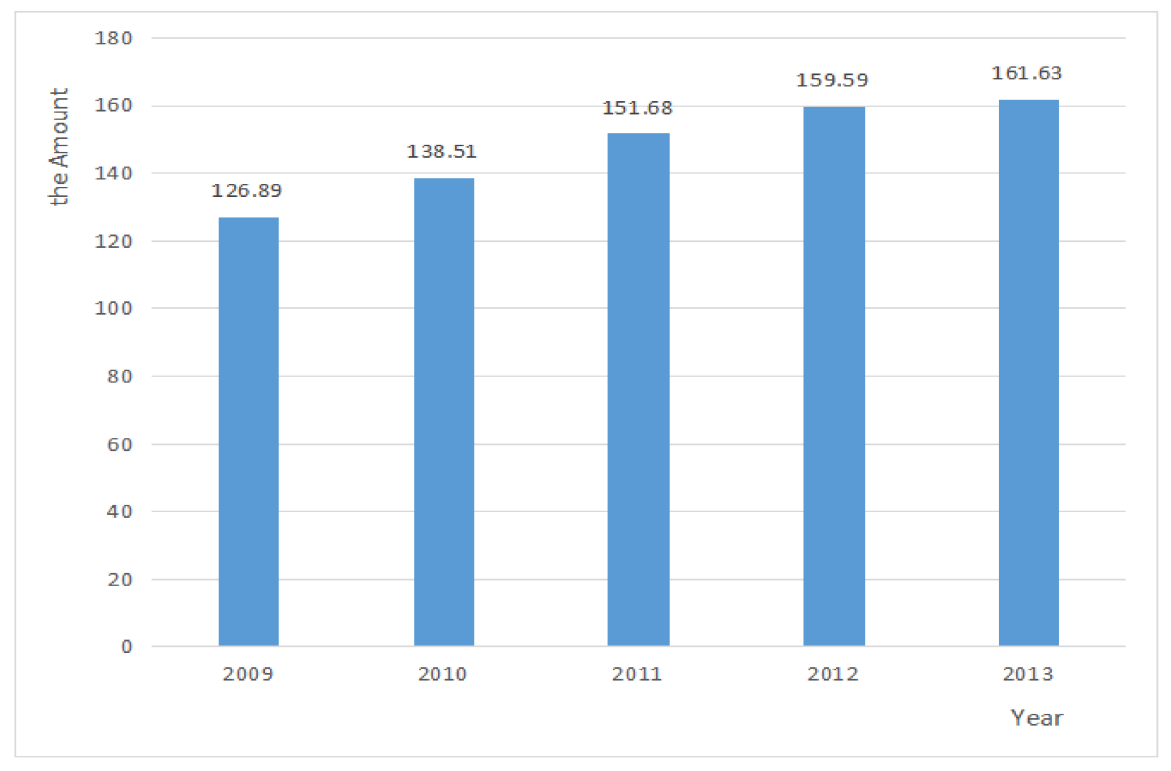

Figure 2. Amount of energy consumption in rural China in 2009-2013 (trillion ton).

\section{Research Methodology}

A SWOT analysis approach is used to study the strategic planning of enterprises or industries. This approach was initially adopted in business and marketing disciplines, and it has gradually been applied to various fields. For example, Ke, et al. [23] conducted a SWOT analysis for domestic private enterprises dealing with the development of infrastructure projects in China and concluded that the methodology is a useful tool for assessing continuous changes. SWOT analysis has been employed in renewable energy management [24-26], construction waste management [6], off-site construction [27], and building energy conservation [28]. Thus, SWOT analysis is a good approach for strategic planning research.

In the present study, SWOT analysis was employed to identify the factors that affect the promotion of RBEE. Weaknesses and threats could be overcome by following the principles of maximizing strengths and taking advantage of opportunities. A framework of the SWOT analysis (Figure 3) was proposed on the basis of the work in Reference [27]. In step 1, a generic framework was formulated to identify the RBEE factors. On the basis of the research of Shen, et al. [29], we classified the factors as those that affect RBEE's strengths and weaknesses (SW), including management ability, technological ability, financial ability, organization, and operations; and those that affect RBEE's opportunities and threats (OT), including social and political environments, economic environment, market opportunities, and competition mechanism.

In step 2, a list of strengths, weakness, opportunities, and threats of RBEE was derived from the literature review, governmental reports, and semi-structured interviews. The questions for the semi-structured interviews were modified and finalized after a brainstorming discussion among the researchers. The main research questions designed for the semi-structured interviews are presented in Table 1. Ten interviewees from Shandong Province, which comprised two officials in the government sector, two village leaders, two rural residents, one university researcher, one designer, one project manager, and one green building material supplier, were selected. All of the participants were stakeholders in RBEE with a relatively in-depth understanding of energy consumption in rural regions. 
Semi-structured interviews were carried out in February 2017, and each interview session lasted for 30-40 min. Table 2 shows the profile of the interviewees.

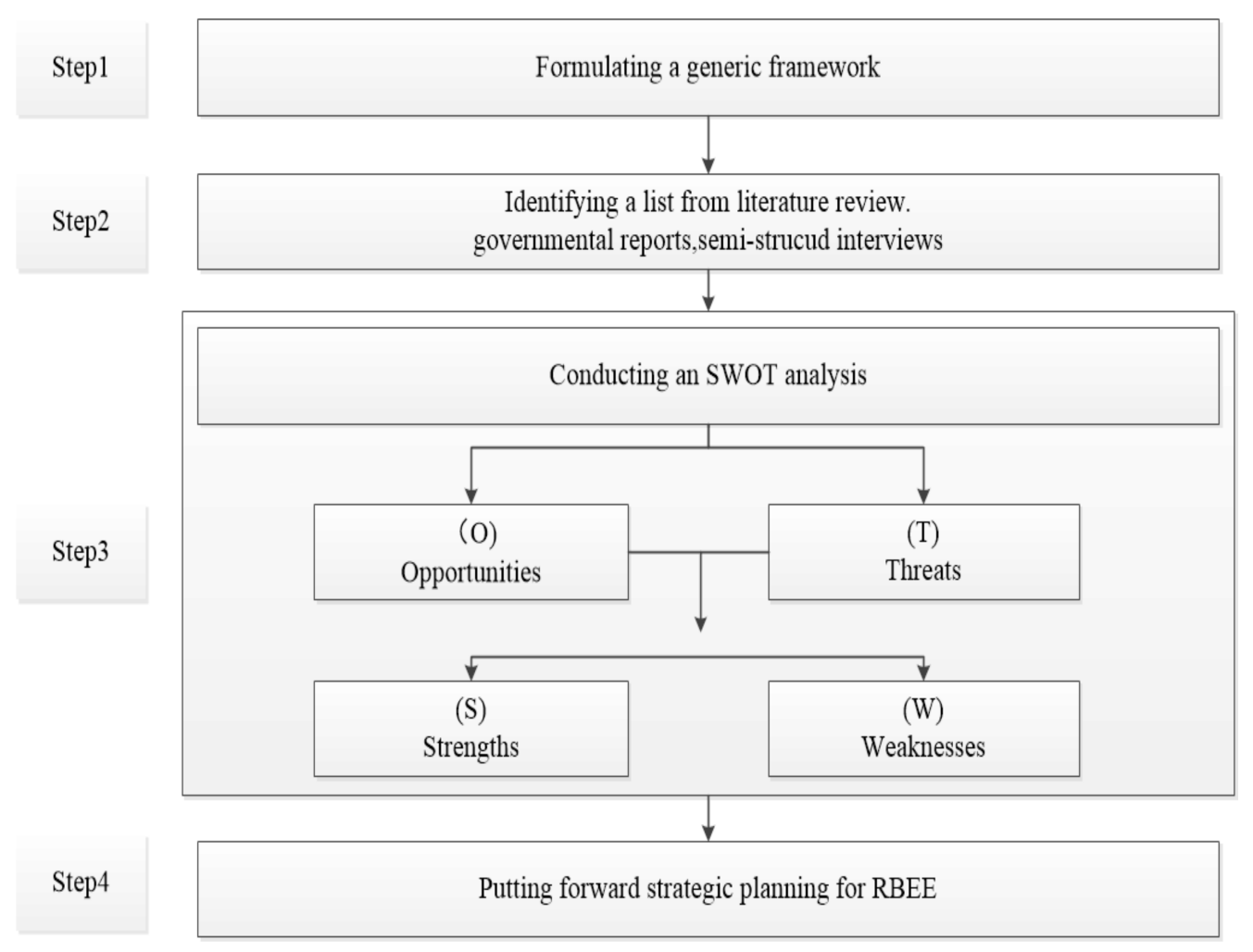

Figure 3. The basic flow of research [27].

Table 1. Main questions for semi-structured interviews.

\begin{tabular}{cll}
\hline Code & \multicolumn{1}{c}{ Question } & \multicolumn{1}{c}{ Explanation } \\
\hline Q1 & $\begin{array}{l}\text { What are the opportunities for Rural } \\
\text { Building Energy Efficiency (RBEE)? }\end{array}$ & $\begin{array}{l}\text { What are the external prospects that can be taken } \\
\text { advantage of for RBEE? }\end{array}$ \\
\cline { 3 - 3 } Q2 & What are the threats to RBEE? & $\begin{array}{l}\text { What is the governmental guidance for promoting RBEE? } \\
\text { development of RBEE? }\end{array}$ \\
\hline Q3 & What are the strengths of RBEE? & What are the benefits of promoting RBEE? \\
\hline Q4 & What are the weaknesses of RBEE? & $\begin{array}{l}\text { What are the internal negative factors that restrict the } \\
\text { development of RBEE? }\end{array}$ \\
\hline
\end{tabular}

Table 2. Profile of the interviewees.

\begin{tabular}{lccc}
\hline $\mathbf{N}$ & Position & Company & Number \\
\hline 1 & Project manager & Safety construction company in Changqing County in East China & 1 \\
2 & Village leader & Zhou Village in Zhangqiu County & 2 \\
3 & Rural resident & Zhou Village in Zhangqiu County & 2 \\
4 & Researcher & Shandong Jianzhu University & 1 \\
5 & Designer & Tong Yuan Design Company & 1 \\
6 & Green building material supplier & Thermal insulation material company & 1 \\
7 & Official & Department of Village and Town & 1 \\
8 & Official & Department of Energy Conservation Science and Technology & 1 \\
\hline
\end{tabular}


The answers to the questions were abstracted to establish a list of SWOT analysis factors. On the basis of the literature review and governmental reports, the SWOT factors related to RBEE were initially identified. In step 3, six experts were invited to evaluate the reliability of the SWOT factors. In the evaluation, unsuitable factors, such as the number of migrants to cities, were removed, and important factors, such as low income of rural residents, were added. The final list of SWOT factors was finally attained after the evaluation. On the basis of the aforementioned analysis, we adopted a research method for integrating stakeholder analysis into the SWOT analysis. In step 4, five concrete strategic action plans were proposed for the government to promote RBEE.

\section{SWOT Analysis of RBEE in Rural China}

The SWOT analysis begins with "O $+\mathrm{T}$ " and ends with " $\mathrm{S}+\mathrm{W}$ ". The matrix of the SWOT analysis is established according to the literature review, governmental reports, and semi-structured interviews, as shown in Table 3, which sets forth the identified SWOT factors, types, and sources of origin [27]. The opportunities, threats, strengths, and weaknesses are discussed in detail to deepen the understanding of the current situation of RBEE in China.

Table 3. The matrix of strength-weakness-opportunity-threat (SWOT) analysis.

\begin{tabular}{|c|c|c|c|}
\hline Analysis & SWOT & Type & Source \\
\hline \multirow{6}{*}{ “O + T” Analysis } & O1-top-to-bottom policy support & G & $\begin{array}{l}\text { MOHURD, 13th Five-Year for Building } \\
\text { Energy-Saving and Green Building Plan } \\
(2016-2020)\end{array}$ \\
\hline & $\begin{array}{l}\text { O2-new socialist initiatives in } \\
\text { the countryside }\end{array}$ & $\mathrm{G}, \mathrm{L}$ & $\begin{array}{l}\text { Yang, et al. [30], Proposal of the Central Committee } \\
\text { of the Chinese Communist Party for the 11th } \\
\text { Five-Year Plan for national economic and social } \\
\text { development }\end{array}$ \\
\hline & O3-appeals for enhancing RBEE & $\mathrm{G}, \mathrm{L}$ & $\begin{array}{l}\text { Wu, et al. [31], Development of Chinese BEE } \\
\text { Report in } 2016\end{array}$ \\
\hline & T1-lack of policies and standards & $\mathrm{L}, \mathrm{I}$ & Sha and $\mathrm{Wu}[32]$ \\
\hline & $\begin{array}{l}\text { T2-unreasonable energy } \\
\text { structure }\end{array}$ & $\mathrm{L}, \mathrm{I}, \mathrm{G}$ & $\begin{array}{l}\text { Zhang, et al. [33], Guidance on Expanding BEE } \\
\text { Pilot Project in 2009, official from the Department } \\
\text { of Energy Conservation Science and Technology }\end{array}$ \\
\hline & $\begin{array}{l}\text { T3-lack of supervising } \\
\text { mechanism }\end{array}$ & $\mathrm{I}, \mathrm{G}$ & $\begin{array}{l}\text { An official from the Department of Village and } \\
\text { Town, 13th Five-Year Plan for Building } \\
\text { Energy-Saving and Green Building Development }\end{array}$ \\
\hline \multirow{6}{*}{ “S + W” Analysis } & $\begin{array}{l}\text { S1-significant energy efficiency } \\
\text { potential }\end{array}$ & $\mathrm{L}, \mathrm{I}, \mathrm{G}$ & $\begin{array}{l}\text { He, Yang, Ye, Mou and Zhou [1], Li, et al. [34], an } \\
\text { official from the Department of Village and Town, } \\
\text { notice of carrying out the green rural housing } \\
\text { construction in } 2013\end{array}$ \\
\hline & $\begin{array}{l}\text { S2-abundant renewable energy } \\
\text { resources }\end{array}$ & $\mathrm{L}, \mathrm{G}$ & $\begin{array}{l}\text { Zhang, et al. [35], Development of Chinese BEE } \\
\text { Report in } 2016\end{array}$ \\
\hline & $\begin{array}{l}\text { S3-requirements for improving } \\
\text { living comfort }\end{array}$ & $\mathrm{L}, \mathrm{I}$ & Wu, Liu and Qin [31], rural resident, village leaders \\
\hline & $\begin{array}{l}\text { W1-poor building energy-saving } \\
\text { consciousness }\end{array}$ & $\mathrm{L}, \mathrm{I}$ & $\begin{array}{l}\text { Ai, et al. [36], an official from the Department of } \\
\text { Village and Town in Shandong Province }\end{array}$ \\
\hline & $\begin{array}{l}\text { W2-inadequate knowledge and } \\
\text { information }\end{array}$ & $\mathrm{L}, \mathrm{I}$ & Wimala, et al. [37], village leaders \\
\hline & $\begin{array}{l}\text { W3-low-income level of rural } \\
\text { residents }\end{array}$ & $\mathrm{L}, \mathrm{I}$ & Sha and $\mathrm{Wu}[32]$, village leaders \\
\hline
\end{tabular}

NOTE: Literature review (L); semi-structured interviews (I); governmental reports (G).

\subsection{Opportunities}

\subsubsection{O1-Top-to-Bottom Policy Support}

In the contexts of environmental degradation and energy crisis, "ecological civilization construction", especially in rural regions, is noted as a crucial topic in the report of the 19th National Congress of Communist Party in China. The BEE in rural regions has received considerable attention from governmental reports. Governmental reports related to RBEE are shown in Table 4. RBEE is expected to attain significant top-to-bottom policy support in the future. 
Table 4. Governmental reports related to RBEE.

\begin{tabular}{|c|c|c|c|}
\hline Year & Regulations & Issuers & Contents Regarding RBEE \\
\hline 2009 & $\begin{array}{l}\text { Accelerating the implementation } \\
\text { of renewable energy building } \\
\text { applications in rural areas }\end{array}$ & MOF, MOHURD & $\begin{array}{l}\text { Renewable energy resources used in rural } \\
\text { schools, rural residential buildings, } \\
\text { village or town governmental offices, and } \\
\text { health centers }\end{array}$ \\
\hline 2009 & $\begin{array}{l}\text { Guidance on Expanding BEE Pilot } \\
\text { Project for Dangerous Rural } \\
\text { Reconstruction }\end{array}$ & MOHURD & $\begin{array}{l}\text { Focusing on energy-saving measures for } \\
\text { building envelopes in walls, doors, roofs, } \\
\text { and windows to improve the thermal } \\
\text { comfort of rural residential buildings }\end{array}$ \\
\hline 2013 & Green Building Action Plan & $\begin{array}{l}\text { Office of the State } \\
\text { Council }\end{array}$ & $\begin{array}{l}\text { Promoting green rural housing } \\
\text { construction, preparing technical guides } \\
\text { for green buildings in villages or towns, } \\
\text { freely providing technical services }\end{array}$ \\
\hline 2013 & $\begin{array}{l}\text { Notice of carrying out green rural } \\
\text { housing construction }\end{array}$ & $\begin{array}{l}\text { MOIIT, } \\
\text { MOHURD }\end{array}$ & $\begin{array}{l}\text { Exploring green rural housing } \\
\text { construction method and technology; } \\
\text { popularizing native green buildings; } \\
\text { promoting green building materials to the } \\
\text { countryside; demonstrating project of } \\
\text { green rural housing }\end{array}$ \\
\hline 2015 & $\begin{array}{l}\text { Action Plan to Promote the } \\
\text { Production and Application of } \\
\text { Green Building Materials }\end{array}$ & $\begin{array}{l}\text { MOIIT, } \\
\text { MOHURD }\end{array}$ & $\begin{array}{l}\text { Promoting green building materials to the } \\
\text { countryside; preparing a green material } \\
\text { product catalog for green rural housing }\end{array}$ \\
\hline 2017 & $\begin{array}{l}\text { 13th Five-Year Plan for Building } \\
\text { Energy-Saving and Green } \\
\text { Building Development }\end{array}$ & MOHURD & $\begin{array}{l}\text { Economically developed areas and key } \\
\text { development areas should make a } \\
\text { breakthrough in RBEE, and the } \\
\text { proportion of energy-saving measures } \\
\text { should be over } 10 \%\end{array}$ \\
\hline
\end{tabular}

Note: Ministry of Finance (MOF); Office of the State Council (OOSC); Ministry of Housing and Urban-Rural Development (MOHURD); Ministry of Industry and Information Technology (MOIIT).

\subsubsection{O2-New Socialist Initiatives in the Countryside}

Influenced by the long-term dual systems in China, the developments in urban and rural regions are unbalanced, and most rural residents remain relatively poor. In this context, new socialist initiatives in the countryside were introduced as part of the national strategic plan in the 1950s. However, such initiatives had not essentially played a significant role until the proposal of the Central Committee of the Chinese Communist Party on the 11th Five-Year Plan for National Economic and Social Development was issued.

In 2017, the central government proposed a national strategy called "Rural Revitalization", which aimed to construct an eco-friendly, livable, luxurious, and flourishing industrial countryside. The government is expected to attach high importance to the "problems of agricultural and rural areas" in the new era of socialism. The living environment will be markedly improved with the new socialist initiatives in the countryside. Driven by the construction of new socialist initiatives in the countryside at the national level, great opportunities for RBEE can be expected.

\subsubsection{O3-Appeals for Enhancing RBEE}

The "13th Five-Year Plan for National Economic and Social Development (2016-2020)" in China requires reducing the energy consumption per unit of gross domestic product (GDP) by $15 \%$ and the $\mathrm{CO}_{2}$ emission per unit of GDP by $18 \%$. Reducing the energy consumption in the construction industry is crucial to realize the macro goal. Furthermore, addressing the high energy consumption and low energy efficiency of rural buildings is an urgent appeal. With the development of urbanization and agricultural modernization, a growing number of rural residents are likely to pursue a high-quality 
living environment. Echoed by the semi-structure interviews in the current work, enhancing RBEE is the best choice to realize the target of "beautiful countryside construction" at the national level.

\subsection{Threats}

\subsubsection{T1—Lack of Policies and Standards}

The legal environment is the major factor that affects the implementation of BEE [38]. Although the local government implemented the Energy Conservation Law in 2008, specific details related to buildings are lacking. Moreover, the existing standard system for BEE design remains imperfect. Most of the standards focus on urban buildings. Only one national standard exists for rural regions, that is, "The design standard for energy efficiency of rural residential buildings", which was launched in 2012 [8]. Several actions have been implemented in relation to RBEE, and they include "Promoting Renewable Energy in Rural Areas", "Dangerous Residential Reconstruction based on Energy-Saving Retrofitting", and "New Types of Green Construction Materials for the Countryside" [9]. Nevertheless, all these actions cover relatively limited rural regions. Most provinces and regions have yet to officially carry out energy efficiency actions [39]. The lack of policies and standards hinders the development of RBEE.

\subsubsection{T2-Unreasonable Energy Structure}

The energy structure in rural China is more unreasonable than that in the urban areas [40]. In rural households, traditional biomass is the dominant fuel, accounting for over $75 \%$ of the rural building energy use in 2005 [2]. With growing earnings of rural residents, they gradually switch from traditional biomass to commercial energy, especially coal. The energy structure in rural buildings remains dominated by coal and electricity. The proportions of electricity and coal are $41 \%$ and $44 \%$, respectively, as depicted in Figure 4. Coal is used for terminal consumption in rural buildings, but it results in low energy efficiency and severe environmental pollution. Therefore, the unreasonable energy structure is a significant threat to the sustainable development of RBEE.

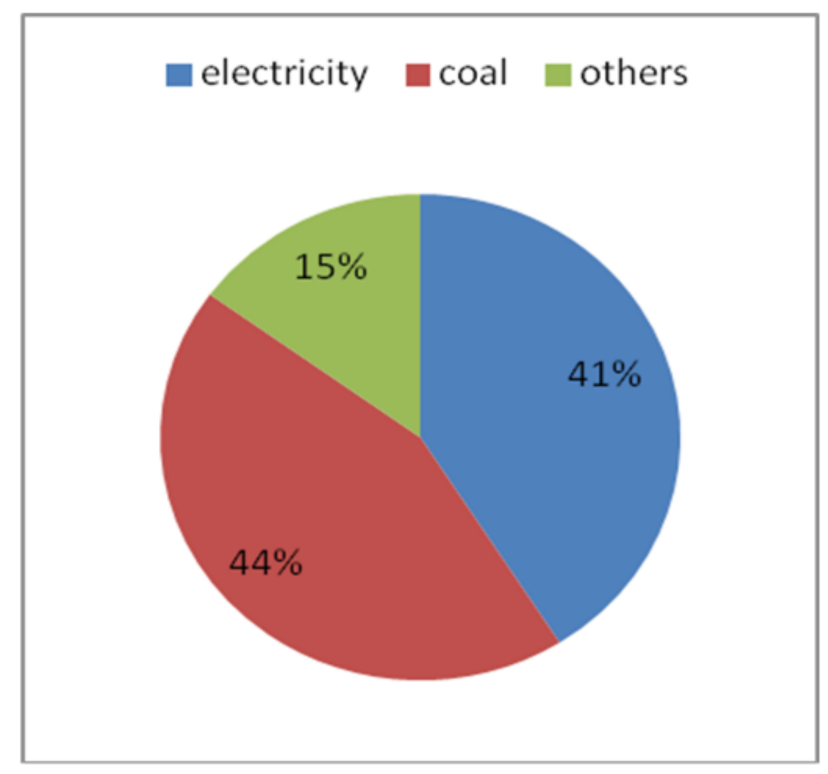

Figure 4. Energy structure in rural Chinese buildings in 2013 [22].

The findings of a survey by the Building Energy Efficiency Research Center of Tsinghua University (BEERCTU) in 2006-2007 revealed that the energy consumption in rural regions accounts for 37\% of the total [41]. Nonrenewable energy, such as coal and electricity, and renewable energy, such as firewood and straw, contribute to $60 \%$ and $40 \%$ of the total, respectively. Ninety million tons of 
standard coal are consumed annually for heating in northern rural areas [42]. Coal is the main fuel in the energy structure, and it puts great pressure on sustainable development and environmental protection. The unreasonable energy structure is thus an obvious threat to RBEE.

\subsubsection{T3-Lack of Supervision Mechanism}

The current rural market is chaotic. For example, scientific design standards and related supervisory systems are lacking, and rural residents randomly build their own housing. Without any supervision mechanism, rural residents do not voluntarily purchase new energy-efficient building materials [31]. Construction craftsmen, most of which have no professional training in construction and BEE technologies, are hired temporarily. Thus, rural buildings barely have energy-efficient measures. Although the amount of energy consumption for rural heating is 1.5-2 times that for urban heating, the survey of BEERCTU revealed that the indoor temperature in rural areas is significantly lower than that in urban areas [43]. The "Guidance on Improving the Living Environment in Rural Regions" issued by the General Office of the State Council of the People's Republic of China in 2014 required the strengthening of the quality and safety supervision of buildings and the improvement of the energy efficiency rate. Thus, the lack of supervision mechanisms is a major obstacle to the development of RBEE.

\subsection{Strengths}

\subsubsection{S1-Significant Energy Efficiency Potential}

Energy-saving measures are rarely adopted in housing development due to the absence of energy-saving technologies. Consequently, rural buildings present significant energy efficiency potential. For example, external walls are too thin, and they are mainly made of solid clay brick. This type of building material is inefficient for thermal insulation and energy conservation, which requires a large volume of clay, and results in damages to the ecological environment. Moreover, no insulation measures are adopted for external walls and roof. If the temperature rises by 14 degrees, the amount of energy consumption will increase by 1 degree [31]. All of these characteristics result in a considerable heating loss, high energy consumption, and an uncomfortable living environment. According to calculations, only $32 \%$ of heating energy is effectively used [1]. Li, Shan, Yang and Yang [34] concluded that when $30 \%$ and $50 \%$ of rural buildings were involved in energy-efficient retrofitting, the amounts of carbon dioxide emission decreased to 1.14 and 1.9 billion tons, which made up $2.2 \%$ and $3.8 \%$ of the total in 2008 , respectively. Hence, if reasonable green technologies or measures are largely adopted in rural buildings, significant energy efficiency potential will be acquired.

\subsubsection{S2-Abundant Renewable Energy Resources}

As a result of the depletion of fossil energy resources and the increase of environmental pollution, the utilization of renewable energy has attracted considerable attention from around the world. Rural China is rich in renewable energy resources, including solar, geothermal, wind, and biomass energy. All of them are clean, pollution-free, and widely distributed [8]. Annually, the utilization of renewable energy resources in China is approximately 3 billion and 600 million tons standard coal, and in 2009, the total energy consumption reached 3 billion and 100 million tons [44]. Abundant renewable energy resources are available in China. For example, two-thirds of the country's territories can receive more than 2200 sunshine hours every year [45], and the same is especially true in vast rural areas. They are also naturally endowed with plenty of biomass resources, which serve as a rich source for biogas utilization. Biogas can be used for cooking and lighting for people's daily activities, and thus can greatly decrease indoor air pollution and reduce greenhouse gas emissions caused by the direct combustion of firewood and coal. In sum, abundant renewable energy resources represent a significant strength that favors the promotion of RBEE. 


\subsubsection{S3-Requirements for Improving Living Comfort}

$\mathrm{Wu}$, Liu and Qin [31] conducted a survey in northern China and found that the increase in rural residents' income also gradually enhances the demand for quality of life. Rural residents thus pursue high levels of comfort in terms of heating, cooking, etc. This condition is in accordance with our findings from the semi-structured interviews.

Approximately $95 \%$ of the rural residents surveyed hold strong demands for heating in winter [39]. An indoor temperature below $12{ }^{\circ} \mathrm{C}$ is difficult to bear. In addition, several rural residents have shifted their cooking mode from traditional firewood and straw, which is characterized by low energy efficiency and poor indoor environment, to convenient commercial energy resources. Rural residents also pursue large housing [2], with the average housing space increasing from $22.5 \mathrm{~m}^{2}$ in 2001 to $28.2 \mathrm{~m}^{2}$ in 2008 [31], thus implying a greater demand for energy consumption. In sum, the requirement for improving living comfort can enhance rural residents' willingness to consider RBEE.

\subsection{Weaknesses}

\subsubsection{W1-Poor Energy Efficiency Awareness}

Most rural buildings are built by rural residents themselves. Hence, the application of energy-saving technologies is limited. The resulting poor performance of thermal insulation then leads to uncontrollable energy losses. With the concepts of abundant resources and inexhaustible energy, rural residents seldom pay attention to the issue of energy efficiency. They primarily focus on the appearance and large size of living spaces for their homes. For example, when they accumulate funds to build their homes, they are inclined to focus on aesthetic qualities and neglect energy efficiency [36]. Owing to the social norms termed as the "bandwagon effect" in rural regions, other rural residents will behave in the same way. This behavior greatly restricts the popularization of energy efficiency in rural China. Obviously, poor energy efficiency awareness is an obstacle for RBEE.

\subsubsection{W2-Inadequate Knowledge and Information}

Rural buildings in China are generally built without the aid of professional design and construction practitioners. Most rural residents neglect the problems of energy efficiency because of their lack of relevant knowledge and information. Unlike urban residents, rural residents mostly have low education levels. Moreover, rural residents are unfamiliar with the benefits of BEE, leading to the difficult promotion of RBEE. Limited channels are available to receive information about BEE, with the main channels being TV broadcasts. From this top-to-bottom communication approach, a long period is required for rural residents to receive timely information about the government's technological support and economic subsidies. Inadequate knowledge and information is an obvious weakness that remarkably hinders the promotion of RBEE.

\subsubsection{W3-Low Income of Rural Residents}

Most rural residents in China are engaged in small-scale natural agriculture, which equates to a relatively low income. In the context of rapid urbanization, an increasing number of rural residents are moving to cities, with $16.4 \%$ of them aiming to work as construction workers and $21.1 \%$ of them securing positions in the service industry [46]. Although their income has gradually increased, rural residents significantly differ from urban residents. The income difference between rural and urban residents from 2012 to 2016 based on 2017 statistical data is shown in Figure 5. The increasing gap can be recognized starting in 2012. Currently, the income of some rural residents can only meet their basic living needs. Rural residents' own funds are utterly inadequate for BEE [32]. Such low income prevents rural residents from purchasing expensive energy-saving lamps and energy-efficient electric appliances or installing solar energy facilities. Therefore, the low income of rural residents is a weakness in RBEE promotion. 


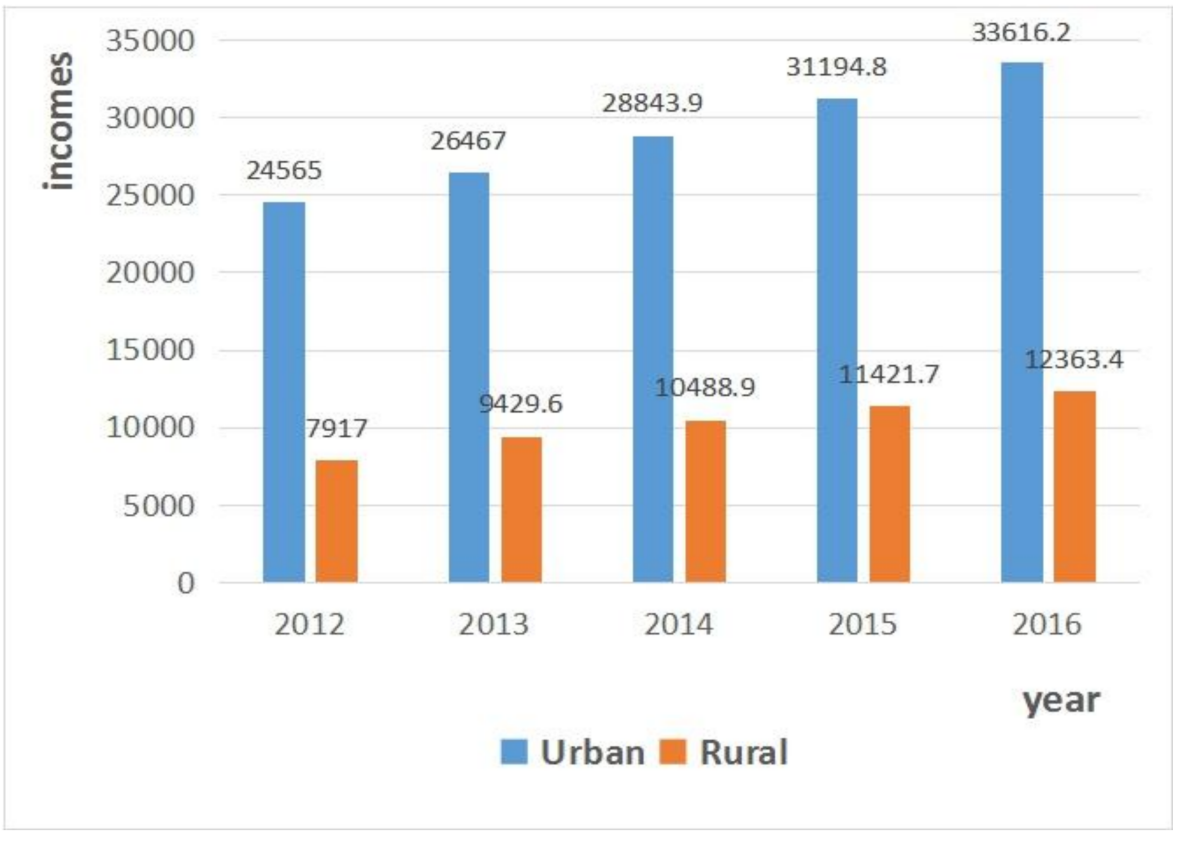

Figure 5. Incomes of urban and rural residents in 2012-2016.

\section{Strategies for Promoting RBEE}

A list of critical strategic plans for RBEE can be formulated according to the SWOT analysis matrix in Table 5. The principles behind the proposal of these strategies are modified from Yuan [6] and are described as "maximizing strengths and opportunities, transforming weaknesses to strengths, and neutralizing threats". The key strategies are comprehensively examined to underline the strategies and planning.

Table 5. Strategic planning based on the SWOT analysis matrix for RBEE.

\begin{tabular}{|c|c|c|}
\hline Environment & & Planning \\
\hline \multirow{2}{*}{ External Environment } & Opportunities (O) & $\begin{array}{l}\text { 1. Top-to-bottom policy support; } \\
\text { 2. Construction of new socialist initiatives in the countryside; } \\
\text { 3. Appeals for enhancing RBEE. }\end{array}$ \\
\hline & Threats $(\mathrm{T})$ & $\begin{array}{l}\text { 1. Lack of policies and standards; } \\
\text { 2. Unreasonable energy structure; } \\
\text { 3. Lack of supervision mechanism. }\end{array}$ \\
\hline \multirow{6}{*}{ Internal Environment } & Strengths (S) & $\begin{array}{l}\text { 1. Significant energy efficiency potential; } \\
\text { 2. Abundant renewable energy resources; } \\
\text { 3. Requirements for improving living comfort. }\end{array}$ \\
\hline & Weaknesses (W) & $\begin{array}{l}\text { 1. Poor energy efficiency awareness; } \\
\text { 2. Inadequate knowledge and information; } \\
\text { 3. Low income of rural residents. }\end{array}$ \\
\hline & SO strategies & $\begin{array}{l}\text { S2: Establishing technology Research and Development } \\
\text { (R\&D) institutions in local regions; } \\
\text { S3: Promoting demonstration projects of RBEE. }\end{array}$ \\
\hline & WO strategies & $\begin{array}{l}\text { S4: Carrying out RBEE training; } \\
\text { S5: Providing economic subsidies to rural residents. }\end{array}$ \\
\hline & ST strategies & $\begin{array}{l}\text { S1: Formulating a carrot-and-stick policy governance } \\
\text { mechanism; } \\
\text { S3: Promoting demonstration projects of RBEE. }\end{array}$ \\
\hline & WT strategies & $\begin{array}{l}\text { S1: Formulating a carrot-and-stick policy governance } \\
\text { mechanism; } \\
\text { S5: Providing economic subsidies to rural residents. }\end{array}$ \\
\hline
\end{tabular}




\subsection{Strategy 1-Formulating a Carrot-and-Stick Policy Governance Mechanism}

A guidance policy plays a critical role in promoting RBEE. In the work of Wu and Yin [9], a questionnaire survey was distributed to experts in $17 \mathrm{BEE}$ institutions, and policies were noted to have a more important role than technologies. According to different degrees of strictness of policies issued by the government, the three BEE policy instruments are voluntary scheme instrument, economic incentive instrument, and mandatory administration [47]. Only one standard code, the "Design Standard of BEE in Rural Regions", exists, but it is not mandatory. Stakeholders hardly comply with construction codes due to the lack of capital support and technical guidance in implemented standards. Thus, an appropriate governance mechanism should be established.

The "carrot-and-stick" strategies are among the best choices. A countryside-oriented policy governance mechanism is required to guarantee the implementation of technological and financing strategies. Mandatory administration and economic incentive instruments are equally critical. On the one hand, the government should establish a penalty system that forbids rural residents from using solid clay bricks. On the other hand, the government should formulate an economic incentive system that encompasses preferential policies in terms of governmental subsidies. This system should be interest-free to encourage rural residents to adopt inexpensive and practical green technologies or renewable energy sources.

\subsection{Strategy 2-Establishing Technology RED Institutions in Local Regions}

Research on building energy-saving technologies has mainly focused on cities, and the energy conservation goals and mandatory standards issued by the government are mostly targeted at urban buildings. The construction specifications for rural buildings is remarkably different from those for urban ones due to different lifestyles and economic conditions. A reasonable technology is an effective channel to solve the problems in energy efficiency. Therefore, technology research, development, and promotion are vital. Materials and construction techniques in rural regions are remarkably distinct. Local governments should encourage local universities or institutions to establish R\&D centers. The centers can be combined with enterprises and universities to establish a platform of "production, learning, and research" to work out low-cost and energy-efficient technological solutions, which suit local climate conditions and geographic characteristics. Developing and utilizing renewable energy resources in rural regions are also beneficial actions. In terms of climate and regional characteristics, thermal insulation technology and "Kang" can be promoted in the northern countryside, which can utilize solar energy for heating. In the southern countryside, eco-villages can be constructed through the development of passive housing technology and biogas pools for cooking and heating.

\subsection{Strategy 3-Promoting Demonstration Projects of RBEE}

The central government has launched a series of energy-efficient pilot programs for public and residential buildings in certain urban regions. The resulting experiences can be applied to RBEE. For example, the Beijing government launched the action initiative "Management Method of the Demonstration Project of Utilization of Innovative Wall Material for BEE in the Rural Residents" in 2007. By meeting stipulated conditions, rural residents could be awarded 20 thousand Chinese Yuan to subsidize the incremental cost of innovative wall materials. Although the scope of demonstration projects is limited to some developed rural regions, numerous rural residents will gradually know about the economic benefits and advantages of a healthy living environment through demonstration projects. These demonstration projects can be expanded to other regions. A prefabrication construction approach can be employed in the demonstration projects to speed up the development of high-quality structures and reduce energy consumption and carbon emissions [48]. Therefore, this approach shows great promise when implemented in rural buildings. 


\subsection{Strategy 4-Carrying out RBEE Training}

Training is an effective approach to promote RBEE. Training can raise rural residents' awareness of RBEE and improve the energy efficiency skills of construction craftsmen. Conducting effective training is especially difficult for rural residents due to their low level of education and traditional lifestyle. Most of them are unfamiliar with the advantages of energy-efficient technologies. Thus, the training channel and approach should differ from those used in the urban context. Conducting hierarchical top-to-bottom training is practical. The central or local government first focuses on the training of village organizations and their leaders. With complete knowledge about renewable energy technologies, economic benefits, and governmental subsidies, these trained individuals can serve as frontrunners in the promotion of RBEE. Village leaders often have the trust of rural residents because they live and work collectively [2]. They can persuade rural residents to change the way they construct new houses or retrofit existing ones through training meetings or oral presentations among rural residents. Training in the area of rural energy efficiency is a prerequisite for construction craftsmen. Local governments should organize these types of training free of charge for building craftsmen so that they have the opportunity to learn about the latest innovative building materials, master green construction technology, and utilize local renewable energy sources.

\subsection{Strategy 5-Providing Economic Subsidies}

To enhance energy efficiency and reduce energy consumption, the government should supply economic incentives to encourage rural residents to adopt renewable energy instead of commercial energy. The government should provide economic incentives to rural residents. Financial support is an essential aspect of RBEE [8]. The cost of building an efficient rural housing is approximately $5 \%$ greater than the cost of building a traditional one [2]. Constructing energy-efficient buildings without any policy intervention is impossible for rural residents due to the externality of BEE. In cooperation with MOF, MOHURD issued a standard for subsidies provided for the use of renewable energy resources in 2009. Under this standard, rural residents can receive 60 Yuan and 15 Yuan per square meter when they apply ground source heat pumps and integrated solar thermal systems, respectively. If individual rural residents use a solar energy bathroom and solar energy housing, $60 \%$ of their incremental cost can be compensated for. The subsidy standards can be adjusted according to the costs incurred in the application of rural renewable energy. In addition, a new energy utilization system for rural buildings must be established. The system should implement energy-saving technologies suitable for rural regions, adjust energy structure, and adopt abundant renewable energy resources, such as solar energy, biomass, and biogas, to improve the livelihood quality of rural residents. The central or local government should supply rural residents with economic incentive strategies to support the utilization of renewable energy.

In the initial stage, the government should set up special funds for R\&D centers. A specific percentage of grants and allowances should be allocated to boost the budget for $R \& D$ that favors green building material production and for standardized module design companies suited for local climate conditions. In addition, the government can provide preferential tax policies, including sales tax and corporate income tax, to renewable energy equipment manufacturers and green building material suppliers. Nevertheless, the policies heavily depend on financial funds. Private firms can be invited to participate in the promotion of RBEE. For instance, public-private partnerships are recommended because they can effectively address limited governmental funds. Employing the approach of energy performance contracting can also lead to a win-win between the government and private investors.

\section{Conclusions}

Driven by the national strategy of constructing new socialist initiatives in the countryside, the conduct of research into BEE in rural China is crucial. With the high energy consumption, low energy efficiency, and poor living comfort in rural China, the improvement of RBEE is an area 
worth exploring. We analyzed the current situation and characteristics of RBEE. On the basis of the literature review, governmental reports, and semi-structured interviews, we performed a SWOT analysis to investigate the opportunities, threats, strengths, and weaknesses of RBEE.

Three opportunities, namely, "top-to-bottom policy support", "construction of new socialist initiatives in the countryside", and "appeal for enhancing RBEE", were identified. The major threats were found to be "lack of policies and standards", "unreasonable energy structure", and "lack of supervising mechanism". The typical strengths for RBEE included "poor energy efficiency consciousness", "abundant renewable energy resources", and "requirements for improving living comfort". The major weaknesses comprised "poor energy efficiency consciousness", "inadequate knowledge and information", and "low-income level of rural residents". Corresponding strategies were proposed on the basis of the analysis. These strategies involve "formulating a carrot-and-stick policy governance mechanism", "establishing technology R\&D institutions in local regions", "promoting demonstration projects of RBEE", "carrying out RBEE training", and "providing economic subsidies to rural residents". These findings may expand our understanding of the current situation of RBEE in China and provide a valuable strategic plan for improving RBEE.

The process of BEE in the countryside lags far behind that in cities [32]. With its specific features discussed above, RBEE is remarkably distinct from urban BEE. Replicating experiences in the urban context for the rural setting is unreasonable. Therefore, the proposed strategies can be adopted by policymakers to promote RBEE development in the near future. In the context of new urbanization initiatives, existing residential buildings in rural China should be retrofitted to offer significant opportunities to reduce energy consumption and greenhouse gas emissions [49]. The present research mainly focused on the BEE of newly constructed rural buildings. However, the energy efficiency potentials of existing buildings in a real-world situation should not be ignored. Extant studies can offer valuable references [50-54]. Therefore, future studies should consider exploring suitable BEE strategies for existing buildings in rural China.

Acknowledgments: This work was financially supported by the National Social Science Foundation of China (grant number 14BJY060), Shandong Province Social Science Foundation of China (grant number 17CGLJ12), Jinan Social Science Foundation of China (grant number JNSK18DS12), and National Science Foundation of China (grant number 71403150). The authors would like to thank everyone who contributed to the interviews and to the review of the manuscript.

Author Contributions: Lin Zhang and Shan Guo contributed to conceive and design the study; Lin Zhang conducted semi-structured interviews and wrote the paper. Zezhou $\mathrm{Wu}$ analyzed governmental reports and revised the paper. Ahmed Alsaedi and Tasawar Hayat collected and consulted the relevant references.

Conflicts of Interest: The authors declare no conflict of interest.

\section{Nomenclature List}

$\begin{array}{ll}\text { BEE } & \text { Building energy efficiency } \\ \text { RBEE } & \text { Rural building energy efficiency } \\ \text { SWOT } & \text { Strength-weakness-opportunity-threat } \\ \text { MOHURD } & \text { Ministry of Housing and Urban-Rural Development } \\ \text { L } & \text { Literature reviews } \\ \text { I } & \text { Semi-structured interviews } \\ \text { G } & \text { Governmental reports } \\ \text { MOF } & \text { Ministry of Finance } \\ \text { GOOSC } & \text { General Office of the State Council of the People's Republic of China } \\ \text { MOIIT } & \text { Ministry of Industry and Information Technology } \\ \text { BEERCTU } & \text { Building Energy Efficiency Research Center of Tsinghua University }\end{array}$

\section{References}

1. He, B.J.; Yang, L.; Ye, M.; Mou, B.; Zhou, Y. Overview of rural building energy efficiency in China. Energy Policy 2014, 69, 385-396. [CrossRef] 
2. Evans, M.; Yu, S.; Song, B.; Deng, Q.; Liu, J.; Delgado, A. Building energy efficiency in rural China. Energy Policy 2014, 64, 243-251. [CrossRef]

3. 13th Five-Year Plan for Building Energy Saving and Green Building Development. Available online: http:/ / www.mohurd.gov.cn/wjfb/201703/t20170314_230978.html (accessed on 1 March 2017).

4. Lu, S.; Tang, X.; Ji, L.; Tu, D. Research on Energy-Saving Optimization for the Performance Parameters of Rural-Building Shape and Envelope by TRNSYS-GenOpt in Hot Summer and Cold Winter Zone of China. Sustainability 2017, 9, 294. [CrossRef]

5. Yau, Y. Eco-labels and willingness-to-pay: A Hong Kong study. Smart Sustain. Built Environ. 2012, 1, $277-290$. [CrossRef]

6. Yuan, H. A SWOT analysis of successful construction waste management. J. Clean. Prod. 2013, 39, 1-8. [CrossRef]

7. Shan, M.; Wang, P.; Li, J.; Yue, G.; Yang, X. Energy and environment in Chinese rural buildings: Situations, challenges, and intervention strategies. Build. Environ. 2015, 91, 271-282. [CrossRef]

8. He, B.-J.; Yang, L.; Griffy-Brown, C.; Mou, B.; Zhou, Y.-N.; Ye, M. The assessment of building energy efficiency in China rural society: Developing a new theoretical construct. Technol. Soc. 2014, 38, 130-138. [CrossRef]

9. Wu, Y.; Yin, S. Investigating the critical factors to improve rural buildings energy efficiency. J. Constr. Technol. 2014, 16, 70-72. (In Chinese)

10. Liu, W.; Spaargaren, G.; Mol, A.P.J.; Heerink, N.; Wang, C. Low carbon rural housing provision in China: Participation and decision making. J. Rural Stud. 2014, 35, 80-90. [CrossRef]

11. Wang, H.; Wang, L.; Su, F.; Tao, R. Rural residential properties in China: Land use patterns, efficiency and prospects for reform. Habitat Int. 2012, 36, 201-209. [CrossRef]

12. Wang, Y.; Guo, X.; Liu, H. Synthetic evaluation of new socialist countryside construction at county level in China. China Agric. Econ. Rev. 2011, 3, 383-401. [CrossRef]

13. Li, Y.; Jia, L.; Wu, W.; Yan, J.; Liu, Y. Urbanization for rural sustainability-Rethinking China's urbanization strategy. J. Clean. Prod. 2018, 178, 580-586. [CrossRef]

14. Chen, Z.M.; Chen, G.Q. An overview of energy consumption of the globalized world economy. Energy Policy 2011, 39, 5920-5928. [CrossRef]

15. Chen, Z.M.; Chen, G.Q.; Chen, B. Embodied Carbon Dioxide Emission by the Globalized Economy: A Systems Ecological Input-Output Simulation. J. Environ. Inform. 2015, 21, 35-44. [CrossRef]

16. Chen, Z.M.; Chen, G.Q.; Zhou, J.B.; Jiang, M.M.; Chen, B. Ecological input-output modeling for embodied resources and emissions in Chinese economy 2005. Commun. Nonlinear Sci. Numer. Simul. 2010, 15, 1942-1965. [CrossRef]

17. Chen, G.Q.; Guo, S.; Shao, L.; Li, J.S.; Chen, Z.M. Three-scale input-output modeling for urban economy: Carbon emission by Beijing 2007. Commun. Nonlinear Sci. Numer. Simul. 2013, 18, 2493-2506. [CrossRef]

18. Guo, S.; Chen, G.Q. Multi-scale input-output analysis for multiple responsibility entities: Carbon emission by urban economy in Beijing 2007. J. Environ. Account. Manag. 2013, 1, 43-54. [CrossRef]

19. Li, J.S.; Chen, G.Q.; Lai, T.M.; Ahmad, B.; Chen, Z.M.; Shao, L.; Ji, X. Embodied greenhouse gas emission by Macao. Energy Policy 2013, 59, 819-833. [CrossRef]

20. Han, M.Y.; Chen, G.Q.; Shao, L.; Li, J.S.; Alsaedi, A.; Ahmad, B.; Guo, S.; Jiang, M.M.; Ji, X. Embodied energy consumption of building construction engineering: Case study in E-town, Beijing. Energy Build. 2013, 64, 62-72. [CrossRef]

21. Shao, L.; Chen, G.Q.; Chen, Z.M.; Guo, S.; Han, M.Y.; Zhang, B.; Hayat, T.; Alsaedi, A.; Ahmad, B. Systems accounting for energy consumption and carbon emission by building. Commun. Nonlinear Sci. Numer. Simul. 2014, 19, 1859-1873. [CrossRef]

22. STDPC. Report on the Development of Chinese Building Energy Conservation; China Architecture \& Building Press: Beijing, China, 2016. (In Chinese)

23. Ke, Y.; Zhao, X.; Wang, Y.; Wang, S.Q. SWOT analysis of domestic private enterprises in developing infrastructure projects in China. J. Financ. Manag. Prop. Constr. 2013, 14, 152-170. [CrossRef]

24. Chen, W.M.; Kim, H.; Yamaguchi, H. Renewable energy in eastern Asia: Renewable energy policy review and comparative SWOT analysis for promoting renewable energy in Japan, South Korea, and Taiwan. Energy Policy 2014, 74, 319-329. [CrossRef]

25. Jaber, J.O.; Elkarmi, F.; Alasis, E.; Kostas, A. Employment of renewable energy in Jordan: Current status, SWOT and problem analysis. Renew. Sustain. Energy Rev. 2015, 49, 490-499. [CrossRef] 
26. Lupu, A.G.; Dumencu, A.; Atanasiu, M.V.; Panaite, C.E.; Dumitrașcu, G.; Popescu, A. SWOT analysis of the renewable energy sources in Romania-case study: Solar energy. IOP Conf. Ser. Mater. Sci. Eng. 2016, 147, 012138. [CrossRef]

27. Jiang, R.; Mao, C.; Hou, L.; Wu, C.; Tan, J. A SWOT Analysis for Promoting Off-site Construction under the Backdrop of China's New Urbanisation. J. Clean. Prod. 2017, 173, 225-234. [CrossRef]

28. Qin, Y.; Zhang, L. SWOT Analysis for PCDM Development in Building Energy Conservation in China. Energy Procedia 2012, 16, 172-177. [CrossRef]

29. Shen, L.Y.; Zhao, Z.Y.; Drew, D.S. Strengths, Weaknesses, Opportunities, and Threats for Foreign-Invested Construction Enterprises: A China Study. J. Constr. Eng. Manag. 2006, 132, 966-975. [CrossRef]

30. Yang, P.Y.; Zhao, L.Y.; Liu, Z.L. Influences of new socialist countryside construction on the energy strategy of china and the countermeasures. Energy 2010, 35, 698-702. [CrossRef]

31. Wu, Y.; Liu, X.; Qin, L. Study on status, trends and development of building energy efficiency in rural areas in Northern China. J. Build. Sci. 2010, 26, 7-14. (In Chinese)

32. Sha, K.; Wu, S. Multilevel governance for building energy conservation in rural China. Build. Res. Inform. 2016, 44, 619-629. [CrossRef]

33. Zhang, D.; Wang, J.; Lin, Y.; Si, Y.; Huang, C.; Yang, J.; Huang, B.; Li, W. Present situation and future prospect of renewable energy in China. Renew. Sustain. Energy Rev. 2017, 76, 865-871. [CrossRef]

34. Li, Q.; Shan, M.; Yang, M.; Yang, X. Development approach and emission reduction potential of energy saving in rural buildings. J. Constr. Technol. 2010, 5, 40-42. (In Chinese)

35. Zhang, L.; Yang, Z.; Chen, B.; Chen, G. Rural energy in China: Pattern and policy. Renew. Energy 2009, 34 , 2813-2823. [CrossRef]

36. Ai, S.; He, Z.; Shu, W.; Wang, D. Analysis on the difficulties and Countermeasures of energy-saving retrofitting of rural buildings in Chinese hot summer and cold winter areas. Real Estate Biwkly 2017, 9, 204. (In Chinese)

37. Wimala, M.; Akmalah, E.; Sururi, M.R. Breaking through the Barriers to Green Building Movement in Indonesia: Insights from Building Occupants. Energy Procedia 2016, 100, 469-474. [CrossRef]

38. Zhang, Y.; Wang, Y. Barriers' and policies' analysis of China's building energy efficiency. Energy Policy 2013, 62, 768-773. [CrossRef]

39. Peng, C.; Jiang, Y. Roadmap for China's Building Energy Conversation; China Architecture \& Building Press: Beijing, China, 2015.

40. Liu, L.-Q.; Liu, C.-X.; Sun, Z.-Y. A survey of China's low-carbon application practice-Opportunity goes with challenge. Renew. Sustain. Energy Rev. 2011, 15, 2895-2903. [CrossRef]

41. BEECRTU. Research Report on the Annual Development of Chinese Building Energy Conservation; China Architecture \&Building Press: Beijing, China, 2012. (In Chinese)

42. Zhu, J.; Tao, L. Research on Environmental Legal System Innovation in Construction New rural. J. Yunnan Univ. 2011, 24, 78-82. (In Chinese)

43. BEECRTU. Annual Development Report of Chinese Building Energy Saving; China Architecture \&Building Press: Beijing, China, 2008. (In Chinese)

44. Li, H.; Dong, L.; Duan, H. On Comprehensive Evaluation and Optimization of Renewable Energy Development in China. Resour. Sci. 2011, 33, 431-440. (In Chinese)

45. Li, C. Potential Analysis on Energy and Resources of Green Towns in Severe Cold Area. Master's Thesis, Harbin Industrial University, Harbin, China, June 2017. (In Chinese)

46. Ji, S. A Research on Chinese Migrant Workers' Employment Studys. J. Econ. Theory Manag. Res. 2011, 2, 93-99. (In Chinese)

47. Shen, L.; He, B.; Jiao, L.; Song, X.; Zhang, X. Research on the development of main policy instruments for improving building energy-efficiency. J. Clean. Prod. 2016, 112, 1789-1803. [CrossRef]

48. Jaillon, L.; Poon, C.S. Sustainable construction aspects of using prefabrication in dense urban environment: A Hong Kong case study. Constr. Manag. Econ. 2008, 26, 953-966. [CrossRef]

49. Ma, Z.; Cooper, P.; Daly, D.; Ledo, L. Existing building retrofits: Methodology and state-of-the-art. Energy Build. 2012, 55, 889-902. [CrossRef]

50. Lv, S.; Wu, Y. Target-oriented obstacle analysis by PESTEL modeling of energy efficiency retrofit for existing residential buildings in China's northern heating region. Energy Policy 2009, 37, 2098-2101. 
51. Bao, L.; Zhao, J.; Zhu, N. Analysis and proposal of implementation effects of heat metering and energy efficiency retrofit of existing residential buildings in northern heating areas of China in "the 11th Five-Year Plan" period. Energy Policy 2012, 45, 521-528. [CrossRef]

52. Galatioto, A.; Ciulla, G.; Ricciu, R. An overview of energy retrofit actions feasibility on Italian historical buildings. Energy 2017, 137, 991-1000. [CrossRef]

53. Rey, E. Office building retrofitting strategies: Multicriteria approach of an architectural and technical issue. Energy Build. 2004, 36, 367-372. [CrossRef]

54. Asadi, E.; da Silva, M.G.; Antunes, C.H.; Dias, L. Multi-objective optimization for building retrofit strategies: A model and an application. Energy Build. 2012, 44, 81-87. [CrossRef]

C 2018 by the authors. Licensee MDPI, Basel, Switzerland. This article is an open access article distributed under the terms and conditions of the Creative Commons Attribution (CC BY) license (http://creativecommons.org/licenses/by/4.0/). 